\title{
Tradycje i obyczaje szkolne w ,pamięci” nauczycieli oraz uczniów na terenie zaboru austriackiego
}

\begin{abstract}
Polish traditions and customs in schools under Austrian annexation in the light of the diaries and memoirs of teachers and students

The purpose of this article is to explore the traditions and customs commemorated by the school community from the Austrian annexation. It presents their involvement in the celebration of national anniversaries (e. g. the adoption of the Constitution of May 3, the battle of Raclawice, uprisings) and religious ones (including Christmas, Easter, Corpus Christi, All Souls' Day). On the other side, it shows events associated with Polish education (e. g. National Commission of Education day) and also the functioning of the school (school anniversaries, the day of the patron saint of the school). It takes into consideration the ways of commemorating the achievements of people who contributed to the history of Polish learning and culture (e. g. Tadeusz Kościuszko, Adam Mickiewicz, Juliusz Słowacki). In addition, it explores the attitudes of the teachers to Polish traditions and customs. The above issues are illustrated on the basis of selected diaries and memoirs written by pupils and teachers.
\end{abstract}

Keywords: traditions, customs, school community, diaries, memoirs

\section{Uwagi wstępne}

Współcześnie przedstawiciele różnych dyscyplin naukowych, m.in. antropolodzy, filozofowie, socjologowie, historycy wychowania oraz pedagodzy podkreślają wartość tradycji i obyczajów ${ }^{1}$. Wskazują oni potrzebę ich przekazywana kolejnym pokoleniom,

' Publikacje poświecone tradycji: J. Chałasiński, Tradycje i perspektywy przeszlości kultury polskiej, Warszawa 1970; J. Dybiec, Nie tylko szabla: nauka i kultura polska w walce o utrzymanie tożsamości narodowej 1795-1918, Kraków 2004; B. Dymara, W. Korzeniowska, F. Ziemski (red.), Dziecko w świecie tradycji, Kra- 
ponieważ tradycja to największe dziedzictwo każdego narodu, a zarazem czynnik różnicujacy poszczególne narody. W literaturze pojawiło się wiele określeń tego terminu. $W$ ogólnym rozumieniu słowo to pochodzi od łacińskiego określenia traditio, oznaczającego wręczenie, nauczanie, podanie. Władysław Kopaliński podkreślił: tradycja to przekazywanie z pokolenia na pokolenie obyczajów, przekonań, zasad, wierzeń, a także sposobów myślenia, odczuwania, postępowania, wydarzeń z przeszłości traktowanych jako historyczne ${ }^{2}$. Tradycję można definiować jako zbiór praktyk społecznych, na co zwrócił uwagę Jerzy Szacki. Ich celem jest przestrzeganie pewnych norm i wartości, ich podtrzymywanie i przekazywanie, aby zachować pamięć o przeszłości, która ma doniosłe znaczenie dla teraźniejszości i przyszłości³.

Jednak terminu „tradycja” nie można rozpatrywać na gruncie jednej dyscypliny naukowej, ponieważ jest to zjawisko złożone. Z perspektywy poruszanego zagadnienia warto odwołać się do znaczenia, jakie nadają temu słowu przedstawiciele historii oświaty i wychowania oraz pedagogiki ${ }^{4}$. Stanisław Łempicki zwrócił uwagę, że pod nazwa polskich tradycji wychowawczych ujmujemy z całości dorobku edukacyjnego, tylko te idee i ich realizację, które byty świadomie, jako żywotne i szczególnie wartościowe, przekazywane z pokolenia na pokolenie dla dalszego pielegnowania i rozwijania ${ }^{5}$. Podobny pogląd wyraził Julian Dybiec, pisząc: nic tak nie zespala z państwem i nie identyfikuje z ideologiami tworzonymi przez nie jak edukacja. Edukacja prowadzona od najwcześniejszego okresu dzieciństwa wszczepia idee $i$ uczucia, wyrabia przywiazanie do określonej tradycji

ków 2010; J. Goćkowski (red.), Nauka. Tożsamość. Tradycja, Kraków 1995; J. Goćkowski, Tradycja w nauce, „Zeszyty Naukowe UJ, Prace Etnograficzne” 1996, z. 34; M. Halbwachs, Społeczne ramy pamięci, Warszawa 1969; J. Jadczak, Pedagogiczne aspekty dziedziczenia tradycji i tożsamości kulturowej, „Chowanna” 1989, z. 4; S. Łempicki, Polskie tradycje wychowawcze, Warszawa 1936; Z. Mysłakowski, Totalizm czy kultura, Kraków 1938; K. Polak, Tradycja i postęp w pedagogice, „Ruch Pedagogiczny” 1983, nr 1; M. Rożek, Tradycja wiedeńska w Krakowie, Kraków 1983; P. Sierżęga, Obchody 200 rocznicy odsieczy wiedeńskiej w Galicji (1883 r.), Rzeszów 2002; J. Styka, M. Dziekanowka (red.) Tradycja w kontekstach społecznych, Lublin 2011; J. Szacki, Tradycja. Przegląd problematyki, Warszawa 1971; S. Wołoszyn (red.), Nauczyciel: tradycje, wspótczesność, przyszłość. Studia i szkice, Wrocław 1986.

${ }^{2}$ W. Kopaliński, Stownik wyrazów obcych i zwrotów obcojęzycznych, Warszawa 1985, s. 430; Por. Nowa encyklopedia powszechna, red. B. Petrozolin-Sowrońska, Warszawa 1997, T. 6, 434; J. Skrzypczak, Popularna encyklopedia mass mediów, Poznań 1999, s. 582.

Socjolog Jerzy Szacki wyróżnił trzy sposoby rozumienia słowa „tradycja”: czynnościowy (mechanizmy przekazywania dóbr kultury), przedmiotowy (utożsamianie tradycji z dziedzictwem kulturowym i przekazywanymi dobrami), podmiotowy (relacja między dziedzictwem kulturowym a stosunkiem do niego, wyrażanym przez daną grupę społeczną). Zwrócił także uwagę, że z powodu wieloznaczności tego terminu trudno jest stworzyć jedną, powszechnie obowiązującą definicję, jednak jak konkludował: wszystkie rozumienia tradycji, niezależnie od zasadniczych niekiedy różnic między nimi, sa zgodne w uznawaniu jej za fenomen zasadniczo społeczny, inne źródła wiedzy moga mieć charakter indywidualny, tradycja natomiast pojmowana jest zawsze jako korelat jakiejś trwałej grupy społecznej. Natomiast proces przekazywania tradycji odbywa się za pomocą przekazu ustnego, pozawerbalnego (m.in. gesty, zachowania) oraz w sposób pośredni przez środki niewymagające kontaktów międzyludzkich, czyli w postaci słowa drukowanego, zapisu fonicznego czy obrazu.

3 J. Szacki, Tradycja. Przegląd problematyki, Warszawa 1971, s. 97-98.

${ }^{4}$ Problematyka dotycząca tradycji wychowania była podejmowana przez następujących uczonych, m.in. S. Łempickiego, Z. Mysłakowskiego, H. Pohoską, S. Prus-Szczepanowskiego, B. Suchodolskiego.

${ }^{5}$ S. Łempicki, Polskie tradycje wychowawcze, Warszawa 1936, s. 6. 
narodowej i państwowej ${ }^{6}$. Natomiast Władysława Szulakiewicz podkreśliła rolę pedagogiki w procesie krzewienia tradycji. Uznała, że pedagogika winna dążyć do tego, by każda jednostka mogła znaleźć w tradycji coś osobistego, coś na własny użytek, a nie tradycję przez duże »T« [...] Pedagogika tradycji winna mówić (poprzez treści, metody), po co nam znajomość przeszłości, jaki jest jej sens w życiu współczesnego społeczeń$s t w a a^{7}$. W świetle powyższych rozważań należy zaznaczyć, iż przekazywanie tradycji powinno odbywać się w procesie edukacji, aby każda jednostka świadomie brała udział w jej kultywowaniu.

Trzeba także wspomnieć, że z pojęciem tradycja wiąże się również określenie obyczaj, stanowiący formę zachowania, która zostaje powszechnie przyjęta $\mathrm{w}$ danej zbiorowości społecznej oraz poparta uznawaną w niej tradycją. Obyczaj stanowi również element kontroli społecznej, dlatego jego naruszenie może wywołać negatywną reakcję ze strony danej zbiorowości ${ }^{8}$.

Uwzględniając różne znaczenie słów tradycja i obyczaj, warto postawić pytanie, od kogo zależy, czy osoba je pozna, a następnie uzna za swoje i będzie je kultywować? Wiele zależy od ludzi, z którymi będzie przebywać, a przede wszystkim od ich stosunku do tradycji i obyczajów oraz sposobu ich pielęgnowania. Wśród nich ważne rolę pełnią rodzice, a także nauczyciele. Dla zobrazowania tego zagadnienia odwołano się do tradycji i obyczajów szkolnych zachowanych i kultywowanych na terenie zaboru austriackiego. Nawiązując do tej tematyki, postawiono następujące pytania: Jakie tradycje i obyczaje kultywowano w szkole galicyjskiej? W jakim zakresie uczniowie, a w jakim nauczyciele byli zaangażowani w poznanie i pielęgnowanie tradycji i obyczajów szkolnych?

Chcąc przedstawić powyższe zagadnienia, przedmiotem analizy uczyniono dziewiętnastowieczną literaturę pamiętnikarską autorstwa uczniów i nauczycieli, uwzględniając wszystkie szczeble szkolnictwa galicyjskiego. Dla powstania artykułu wykorzystano wybrane źródła pamiętnikarskie 9 .

${ }^{6}$ J. Dybiec, Nie tylko szablą: nauka i kultura polska $w$ walce o utrzymanie tożsamości narodowej 1795-1918, Kraków 2004, s. 283.

${ }^{7}$ W. Szulakiewicz, Gdyby tradycji wychowawczej nie było? Tradycji wychowawczej istota, funkcje i znaczenie, „Przegląd Historyczno-Oświatowy” 1999, nr 3-4, s. 221.

${ }^{8}$ Nowa encyklopedia powszechna, red. B. Petrozolin- Sowrońska, Warszawa 1997, t. 4, s. 573; Por. Stownik języka polskiego, red. M. Szymczak, Warszawa 1981, t. 3.

9 Przykładowe prace pamiętnikarskie wykorzystane w artykule: J. Błoński, Pamiętnik 1891-1939, Kraków 1981; K. Chłędowski, Pamiętnik. Galicja (1843-1880), Kraków 1957; Galicyjskie wspomnienia szkolne, do druku przygot., wstępem i przypisami opatrzył A. Knot, Kraków 1955; Kopiec wspomnień, red. S. Broniewski, Kraków 1959; Księga pamiątkowa 50-lecia Gimnazjum im. Jana Dlugosza we Lwowie, red. W. Kucharski, Lwów 1928; S. Łempicki, Złote paski: wspomnienia ze szkoły galicyjskiej, Warszawa 1957; Szkoła charakterów. Księga Jubileuszowa I Gimnazjum w Liceum w Rzeszowie, oprac. J. Świeboda, Rzeszów 1985; M. Opałek, Gawędy o dawnej szkole, Lwów 1936; idem, O Lwowie i mojej młodości. Kartki z pamiętnika 1881-1901, Wrocław 1987; S. Pigoń, Z Komborni w świat. Wspomnienia młodości, Warszawa 1983; S. Rzepiński, Pamiętnik pięćdziesięcioletniej polskiej pracy pedagogicznej 1885-1935, Kraków 1937. 


\section{Rocznice i święta narodowo-religijne}

Przekazywanie tradycji następnym pokoleniom odbywa się w sposób selektywny. Zazwyczaj następuje proces wartościowania pewnych wydarzeń. Odwołując się do XIX w., najbardziej doniośle świętowano jubileusze na terenie zaboru austriackiego. Wśród nich należy wymienić te upamiętniające: powtórny pochówek Kazimierza Wielkiego (1869 r.), trzechsetletnią rocznicę unii lubelskiej (1869 r.), odsiecz wiedeńską (1883 r. $)^{10}$. W $1872 \mathrm{r}$. zorganizowano obchody stulecia rozbioru Polski, natomiast w 1880 r. świętowano rocznicę powstania listopadowego (1880 r.). Polacy także obchodzili jubileusz Józefa Ignacego Kraszewskiego w 1879 r. czy Jana Długosza. Społeczność galicyjska organizowała również uroczystości związane ze złożeniem zwłok Adama Mickiewicza w katedrze na Wawelu w Krakowie, które odbywały się w dniu 4 lipca 1890 r. Z kolei w 1894 r. upamiętniano działalność Tadeusza Kościuszki, a w 1910 r. zorganizowano obchody bitwy pod Grunwaldem. Dodatkowo corocznie w podniosły sposób podtrzymywano pamięć związaną z uchwaleniem Konstytucji 3 maja ${ }^{11}$. Niewątpliwie pielęgnowanie tych tradycji i obyczajów wynikało z uprawień autonomicznych, jakie Galicja uzyskała w 1860 r. $^{12}$

W kultywowanie tych jubileuszy zaangażowane były różne grupy polskiego społeczeństwa. Wśród nich szczególnie cenny był udział młodzieży szkolnej i nauczycieli w procesie ich „celebrowania”, co potwierdzają źródła pamiętnikarskie. W szkołach galicyjskich pielęgnowano pamięć o ważnych wydarzeniach w życiu szkoły i całego narodu oraz znaczących osobach w dziejach kultury i nauki. Szczególnie aktywnie społeczność szkolna włączała się w obchody związane z kultywowaniem tradycji i obyczajów narodowych. Te elementy kultury mają szczególną rolę w dziejach każdego społeczeństwa. Stanowią one podstawę historycznej ciągłości narodu oraz w istotny stopniu kształtują jego dalsze losy. Przez tradycję narodową poszczególne narody czy wspólnoty narodowe wyrażają własny stosunek do przeszłości. Dlatego ważne staje się włączenie dorobku z przeszłości do świadomości narodowej ${ }^{13}$, czego przykładem może być postawa społeczności szkół galicyjskich. Zarówno nauczyciele, jak i uczniowie angażowali się w manifestacje o charakterze narodowo-religijnym, upamiętniające ważne wydarzenia w dziejach narodu polskiego. Sami także inicjowali różne obchody, w celu zachowania dziedzictwa kulturowego. Dla egzemplifikacji tych zagadnień odwołano się

10 P. Sierżęga, Obchody 200 rocznicy odsieczy wiedeńskiej w Galicji (1883 r.), Rzeszów 2002, s. 7.

Zdaniem Pawła Sierżęgi do najlepiej zorganizowanych jubileuszy poświęconych odsieczy wiedeńskiej należy zaliczyć te z 1783 i 1883 r.

${ }^{11}$ Ibidem.

12 Prace poświęcone autonomii galicyjskiej: R. Dutkowa, Polityka szkolna w Galicji: między autonomią a centralizmem: (1861-1875), Kraków 1995; J. Dybiec, Mecenat naukowy i oświatowy w Galicji 1860-1918, Wrocław 1981; Majorek C., Polska myśl pedagogiczna w zaborze austriackim (1772-1918), „Przegląd Historyczno-Oświatowy” 1992, R. 35; Majorek C., Potoczny J. (red.), Szkice do portretu galicyjskiej pedagogii, Galicja i jej dziedzictwo, T. 9, Rzeszów 1997; J. Potoczny, Oświata dorostych i popularyzacja wiedzy w plebejskich środowiskach Galicji doby konstytucyjnej (1867-1918), Rzeszów 1998.

13 W. Korzeniowska, Bogactwo i różnorodność tradycji w kulturze polskiej, w: Dziecko w świecie tradycji, red. B. Dymara, Wiesława Korzeniowska, F. Ziemski, Kraków 2010, s. 78. 
do źródeł pamiętnikarskich. Wybitny polski historyk oświaty i kultury Stanisław Kot, przywołując czasy szkolne wspominał, że gimnazjum było pod wpływem pradów niepodległościowo-rewolucyjnych, dostarczało starszych uczniów do wszystkich ruchów patriotycznych ${ }^{14}$. Społeczność szkolna z terenu zaboru austriackiego angażowała się w obchody upamiętniające następujące wydarzenia: uchwalenie Konstytucji 3 maja, bitwę pod Racławicami, rocznice powstań narodowych oraz obchody poświęcone upamiętnianiu twórczości wybitnych postaci w dziejach polskiego narodu, m.in. organizowano wieczorki mickiewiczowskie oraz inne spotkania mające na celu przypomnienie działalności osób, zasłużonych w dziejach Polski.

Jak wynika z literatury pamiętnikarskiej społeczność szkolna corocznie szczególnie podniośle obchodziła dzień uchwalenia Konstytucji 3 maja. Przykładowo uczniowie rzeszowskiego gimnazjum rozpoczęli przygotowania do tego święta już dwa tygodnie wcześniej. Jeden z uczestników wspominał: zbieraliśmy się na dziedzińcu szkolnym na musztrę, w czasie której uczono nas maszerować szeregami w pochodzie. Każda klasa miała swego dowódcę z opaską na ramieniu, swego oficera przepasanego szarfa, całe zaś gimnazjum - naczelnego wodza ${ }^{15}$. Natomiast w dniu 3 maja odbywały się właściwe uroczystości. Początkowo nauczyciele i uczniowie zbierali się w auli gimnazjalnej na przygotowanych akademiach, a później wsłuchiwano się w przemówienie jednego z nauczycieli. Uczeń galicyjskiej szkoły zaznaczył, że po zakończeniu tej części uroczystości społeczność szkolna maszerowała ulicami miast do przydrożnego krzyża, gdzie znajdowała się mogiła powstańców z 1863 r. Tam wygłaszano okolicznościowe mowy, a także śpiewano pieśni Boże coś Polskę ${ }^{16}$ lub $Z$ dymem pożarów ${ }^{17}$. Natomiast wybitny pedagog, historyk, poeta, bibliofil Mieczysław Opałek, uczestnicząc w obchodach majowych, wspominał, że tego dnia w kościele gromadziło się wiele osób, wśród których przeważała młodzież akademicka i uczniowie szkół średnich. Po zakończeniu nabożeństwa uczestnicy śpiewali trzy pieśni: Boże, coś Polskę, Boże Ojcze, Twoje dzieci i $Z$ dymem pożarów (Chorat). Dodatkowo zaznaczył, że śpiewano te pieśni $w$ całości zwrotka po zwrotce z zadziwiajaca cierpliwościa $i$ śpiewajacych i organisty, który do końca trwat na chórze przy swym instrumencie ${ }^{18}$. Uczeń rzeszowskiego gimnazjum, uczestnicząc we mszy świętej upamiętniającej uchwalenie Konstytucji 3 maja, na kartach wspomnień pisał: ze tzami w oczach $i$ w dziwnym nastroju opuściliśmy Przybytek Pański, z postanowieniem, że codziennie błagalna tę modlitwe odśpiewaliśmy przez czas trwania

${ }^{14}$ S. Kot, Wspomnienia, w: Szkoła charakterów..., s.

${ }_{15}$ M. Zacharski, Moje wspomnienia z czasów gimnazjalnych, w: Szkoła charakterów..., s. 98.

${ }^{16}$ Boże, coś Polskę - polska, katolicka pieśń religijna. Jej początków należy doszukiwać się w hymnie Alojzego Felińskiego - Boże, zachowaj Króla, który powstał na cześć cara i króla Królestwa Polskiego. Następnie melodia tej pieśni została uproszczona i upodobniona do melodii pieśni religijnej Bądź pozdrowiona, Panienko Maryja. Pieśń zaczęła funkcjonować w obiegu jako pieśń konspirantów, a po klęsce powstania listopadowego stała się manifestacją uczuć patriotycznych.

${ }_{17}$ M. Zacharski, op. cit., s. 99. Z dymem pożarów - była jedną z pieśni, które u schyłku XIX w. pełniły rolę hymnu narodowego. Powstała pod wpływem tragicznych wydarzeń, jakie miały miejsce w 1846 r. - rzezi galicyjskiej.

${ }_{18}$ M. Opałek, O Lwowie i mojej młodości. Kartki z pamiętnika 1881-1901, Wrocław 1987, s. 122. 
nabożeństwa majowego ${ }^{19}$. Z kolei znany historyk literatury polskiej, edytor, wychowawca i pedagog Stanisław Pigoń, wspominał, że uczniowie gimnazjum jasielskiego tego dnia, czyli 3 maja zbierali się, aby wysłuchać przemówienia jednego ze swych kolegów, a następnie śpiewali pieśni narodowe oraz uczestniczyli w pochodzie, który kończył się pod figurę Adama Mickiewicza. Na koniec obchodów odmawiano Litanię pielgrzymstwa autorstwa polskiego wieszcza narodowego ${ }^{20}$.

Zachowane pamiętniki i wspomnienia dokumentują postawę nauczycieli i uczniów, którzy podejmowali zróżnicowane działania, aby podtrzymywać pamięć związaną z uchwaleniem Konstytucji 3 maja, również angażując się w przygotowanie tej uroczystości.

Odwołując się do źródeł pamiętnikarskich, warto wspomnieć, że oprócz uroczystości majowych społeczność galicyjska w celu zachowania tradycji narodowej organizowała wieczorki, aby upamiętnić rocznice powstań narodowych. Jako przykład należy podać te kultywowane we Lwowie. Ich inicjatorem było Towarzystwo Wzajemnej Pomocy Uczestników powstania 1863/1864 r. Spotkania te gromadziły wielu ludzi, w tym również młodzież szkolną i nauczycieli. Wiele informacji na ten temat zachował Mieczysław Opałek, który jako uczeń lwowskiego gimnazjum uczestniczył w tych wieczorkach. Wspominał, że podczas tych uroczystości rozbrzmiewało wiele utworów narodowych m.in. Polonez Kościuszki ${ }^{21}$, Dalej, bracia, do bułata, Co to za gwar, wesoly car, Cześć polskiej ziemi, cześć, a także pojawiały się nowe pieśni w wykonaniu chóru „Echa” oraz innych osób. Istotne było, że utwory te również śpiewali nauczyciele szkół lwowskich. Według zachowanych wspomnień końcowym punktem tych uroczystości był „obraz z żywych osób". W centrum tego obrazu umieszczano najczęściej niewiastę ubraną w białe szaty, zakutą w kajdany jako symbol Polski zniewolonej. Dookoła niej układano bohaterów narodowych począwszy od konfederacji barskiej, przez kosynierów kościuszkowskich, żołnierzy zaangażowanych w powstanie listopadowe, Wiosnę Ludów, do uczestników powstania styczniowego. Na koniec publiczność śpiewała hymn narodowy. W wykonanie tej pieśni włączył się także Mieczysław Opałek, który wspomniał: właczałem się wątym sopranowym głosikiem do tej masówki chóralnej, odczuwając przy tym jakieś ciarki pod skóra i łzy w oczach dziecinnych. Jakaś wielka solenność, jakiś głęboki sens, imperatywna moc promieniowaty z tej pieśni [hymnu narodowego], która nakarmiwszy serca kilku już pokoleń, miała stużyć nowym, idacym - nieśmiertelna, wieczysta ${ }^{22}$.

Oprócz tych uroczystości, młodzież szkolna we własnym zakresie organizowała obchody upamiętniające walki z 1830 r. i 1863 r. Józef Błoński odwołał się pamięcią do czasów szkolnych i wspominał, że razem z kolegą zorganizował zbiórkę pieniędzy wśród młodzieży gimnazjalnej na zakup nowych krzyży dla bohaterów powstań narodowych.

19 E. Webersfeld, Z dawnych wspomnień 1861-1863, w: Szkoła charakterów..., s. 28.

${ }^{20}$ S. Pigoń, Z Komborni w świat. Wspomnienia młodości, Warszawa 1983, s. 195.

${ }^{21}$ Polonez Kościuszki - polska pieśń patriotyczna, która powstała w 1792 r. z okazji przymusowej emigracji Tadeusza Kościuszki, spowodowanej klęską wojsk polskich w wojnie z Rosją i przystąpieniem króla Stanisława Poniatowskiego do Targowicy.

${ }^{22}$ M. Opałek, O Lwowie i mojej młodości..., s. 118. 
Pokreślił, że pod tymi krzyżami corocznie $w$ dniu 1 listopada zbierała się młodzież i publiczność $w$ celu wystuchania okolicznościowych przemówień i odśpiewania pieśni patriotycznych ${ }^{23}$. Z kolei uczeń lwowskiego gimnazjum Mieczysław Opałek zaznaczył, że rocznice powstań obchodzono $w$ atmosferze manifestacji narodowych dojrzewało ziarno czynu. Zaczęto się od religijno-patriotycznej ekstazy, od modłów po kościołach, a zawołaniem, które skupiało i jednoczyło ludzi wszystkich wyznań, stanów i zawodów, stał się podniosły hymn »Boże, coś Polskę ${ }^{24}$. Pieśń ta była coraz częściej i coraz donioślej śpiewana podczas różnych uroczystości jako wyraz tęsknoty ,zniewolonej duszy polskiej”.

Udział w takich uroczystościach pobudzał ducha narodowego w gronie młodych Polaków w zniewolonym kraju, a także stanowił swego rodzaju „szkołę patriotyzmu”.

Wśród społeczności szkolnej ogromnym zainteresowaniem cieszył się także jubileusz związany z rocznicą bitwy pod Racławicami. Ze szczególnym zaangażowaniem uczniowie $\mathrm{z}$ jednej strony uczestniczyli w przygotowanych obchodach upamiętniających to wydarzenie, a z drugiej we własnym zakresie pogłębiali wiedzę na temat tego wydarzenia podczas potajemnych spotkań. Stanisław Pigoń uczestniczył w takich konspiracyjnych zebraniach i na kartach pamiętnika podzielił się odczuciami. Otóż wspominał on, że podczas jednego z nich świętowano rocznicę bitwy pod Racławicami, przede wszystkim przypominano postać Tadeusza Kościuszki ${ }^{25}$. Z literatury pamiętnikarskiej wynika, że młodzież szkolna potajemnie organizowała również inne wieczorki, w celu upamiętnienia dorobku zasłużonych osób dla polskiego narodu. Uczniowie podczas takich potajemnych spotkań wsłuchiwali się w fragmenty utworów dramatycznych polskich pisarzy oraz oglądali występy chóru szkolnego albo sami wystawiali sztuki, takie jak: Odprawa posłów greckich Jana Kochanowskiego, Warszawianka Stanisława Wyspiańskiego, Powrót posła Julina Niemcewicza czy inscenizację Przedświtu Zygmunta Krasińskiego ${ }^{26}$.

Literatura pamiętnikarska potwierdza, że społeczność szkolna włączała się także w obchody poświęcone Adamowi Mickiewiczowi, Juliuszowi Słowackiemu, Marii Konopnickiej. Jednak trzeba zaznaczyć, że szczególnie doniosły charakter miały te upamiętniające dorobek tego pierwszego poety. Przykładowo uczestnik tych konspiracyjnych spotkań Edward Webersfeld ${ }^{27}$ na kartach pamiętnika zaznaczył, że w niedzielę po południu oraz w każde święto uczniowie spotykali się i odczytywali następujące dzieła Adama Mickiewicza - Pan Tadeusz i Konrad Wallenrod, Kordian, a także inne prace polskich poetów. Przepisywali w osobne tomy utwory poetyckie wzbudzające miłość do Ojczyzny. Jak wspominał jeden $\mathrm{z}$ uczestników tych potajemnych zebrań $\mathrm{w}$ ten sposób zaczęliśmy się uczyć pojmowania wyrazów »Ojczyzna $i$ »miłość kraju «"28. Społeczność szkolna równie uroczyście włączyła się w świętowanie dnia 4 lipca 1890 r., kiedy do

23 J. Błoński, Pamiętnik 1891-1939, Kraków 1981, s. 32.

${ }^{24}$ M. Opałek, Gawędy o dawnej szkole, Lwów 1936, s. 133.

25 S. Pigoń, op. cit., s.194.

${ }^{26} \mathrm{~K}$. Machalski, Z działalności organizacji uczniowskich w pierwszych latach międzywojennych w I Gimnazjum w Rzeszowie, w: Szkoła charakterów..., s. 114.

${ }^{27}$ Edward Weberseld (1846-1918) - aktor, dyrektor teatru, autor dramatów, felietonów i artykułów w prasie.

${ }^{28}$ E. Webersfeld, op. cit., s. 27. 
sarkofagu w podziemiach wawelskich sprowadzono z obczyzny prochy polskiego Wieszcza narodowego. W Krakowie rozbrzmiewał dźwięk dzwonu Zygmunta, a we Lwowie, jak wspominał Mieczysław Opałek, dziwny nastrój zapanował, przybranym odświętnie $w$ choragwie o barwach narodowych, $w$ festony $i w$ dywany $u$ okien ${ }^{29}$. Wieczorem w oknach mieszkańców tego miasta płonęły świece w glinianych lichtarzach oraz umieszczano portrety tego poety.

W historii polskiej tradycji, oprócz świąt i rocznic narodowych, ważne miejsce zajmowały uroczystości religijne. Autor wspomnień Stanisław Sobieski podkreślił, że uczniowie aktywnie uczestniczyli w obchodach uroczystości Bożego Ciała ${ }^{30}$ Z okazji tego święta w jednej ze szkół na terenie zaboru austriackiego nauczyciel zobowiązał młodych do zrobienia kołków, zwanych lichtarzami, do których wkładano zapalone świece. Równie podniośle obchodzony był Dzień Zaduszny. Tego listopadowego dnia młodzież brała udział w demonstracjach przy krzyżu powstańców, a także uczestniczyła $\mathrm{w}$ organizowanych pochodach ${ }^{31}$. Obchodzono także zasadnicze święta religijne, takie jak Boże Narodzenie czy Wielkanoc. Przykładowo nauczyciel Jan Tatkowski, kierownik szkoły ludowej w Łące, razem z wychowankami przygotowywał jasełka ${ }^{32}$. Jeden z uczniów, wspominając czasy szkolne, zaznaczył: obyczajowe wychowanie z pociecha wyznać mogę zasadzało się na wielkiej religijności. Nigdy nie opuszczaliśmy mszy świętej. Często przed rozpoczęciem lekcji śpiewaliśmy chórem godzinki, a prawie zawsze »Kto się w opieke i Przed oczy Twoje Panie $\aleph^{33}$.

Należy podkreślić, że udział młodzieży szkolnej w uroczystościach religijnych nie służył jedynie pogłębianiu ich religijności, ale przede wszystkim wychowaniu patriotycznemu. Jak zaznaczył hrabia Władysław Plater, uczestnik powstania listopadowego, działacz emigracyjny i publicysta: dla Narodów, które niepodległość straciły, cóż może być droższym, nad pielęgnowanie ducha, tradycji i pamiątek przeszłości. Sa to nasiona, z których na nowo życie kiedyś odkwitnąć może $e^{34}$. Dlatego ważna była postawa społeczności szkolnej, która włączała się w wiele uroczystości o charakterze narodowo-religijnym.

\section{Tradycje i obyczaje obchodzone w szkołach}

W okresie roku szkolnego nauczyciele i uczniowie, oprócz angażowania się w pielęgnowanie rocznic i świąt narodowo-religijnych kultywowali obchody związane z funkcjonowaniem szkół galicyjskich. W tych instytucjach oświatowych ważne miejsce

\footnotetext{
${ }^{29}$ M. Opałek, O Lwowie i mojej młodości..., s. 84.

${ }^{30}$ S. Sobieski, Wspomnienia dawnego studenta. W szkołach na Pokuciu i Bukowinie 1832-1846, w: Galicyjskie wspomnienia szkolne ..., s. 76.

31 S. Łempicki, Złote paski: wspomnienia ze szkoly galicyjskiej, Warszawa 1957, s. 60.

${ }^{32}$ M. Panek, Wspomnienia szkolne 1894-1902, w: Szkoła charakterów..., s. 37.

${ }^{33}$ L. Powidaj, Oblicze szkoty galicyjskiej w przededniu Wiosny Ludów, w: Galicyjskie wspomnienia szkolne..., s. 133.

${ }^{34}$ M. Rożek, Tradycja wiedeńska w Krakowie, Kraków 1983, s. 59.
} 
zajmowało uroczyste rozpoczęcie roku szkolnego. Tego dnia nauczyciele i uczniowie początkowo gromadzili się w kościele na mszy świętej, a później przemieszczali się do szkoły, w celu wysłuchania przemówienia dyrektora czy jednego z nauczycieli. Według zachowanych wspomnień równie uroczyście obchodzono zakończenie roku szkolnego. Przykładowo w Rzeszowie, tego dnia dekorowano kościół szkolny, zapraszano gości na występy muzyczne wykonywane przez chór i orkiestrę ${ }^{35}$. Szczególnie podniośle świętowano zakończenie roku szkolnego w gimnazjum w Krakowie. Według wspomnień jednego z uczniów budynek szkolny rozbrzmiewat wówczas odgłosem wielkich uroczystości. Jak błyski szpad, krzyżowały się w słownej szermierce pytania profesorów i trafne, rezolutne odpowiedzi uczniów. Niby złote wieńce dożynkowe, sypały się pochwały i nagrody, rosły serca ojców i matek, zaczem kunsztownym i wyszukanym zwrotem chelpity się oracje uczniowskie, budowane wedtug najznakomitszych wzorów poezji i prozy klasycznej $^{36}$. Ten wychowanek krakowskiego gimnazjum dalej zaznaczył $w$ żadnej szkole dawniejszej nie zamknięto roku szkolnego bez podobnej uroczystości ${ }^{37}$.

Zgodnie z zachowanymi źródłami pamiętnikarskimi w tradycje i obyczaje szkół galicyjskich wpisane było obchodzenie różnych rocznic i jubileuszy, związanych z powstaniem poszczególnych instytucji. Dla przykładu w 1900 r. społeczność gimnazjalna w Rzeszowie świętowała stulecie istnienia swojej szkoły. Uroczystość ta trwała trzy dni. Wówczas zajęcia szkolne nie obywały się, a uczniowie zobowiązani byli razem z nauczycielami maszerować ulicami miasta do kościoła na uroczyste nabożeństwo, przy okazji śpiewając pieśni religijne ${ }^{38}$. Społeczność szkolna również obchodziła dzień swojego patrona. W rzeszowskim gimnazjum podniośle świętowano dzień 21 czerwca, czyli dzień patrona tej szkoły - św. Alojzego ${ }^{39}$.

Podczas roku szkolnego nauczyciele i uczniowie angażowali się także w obchody świąt i rocznic, upamiętniających znaczące wydarzenia w dziejach oświaty. Literatura pamiętnikarka dowodzi, że dla społeczności szkolnej szczególne ważne znaczenie miał dzień 14 października. Corocznie w uroczysty sposób podtrzymywano pamięć związaną z utworzeniem pierwszego Ministerstwa Oświaty Publicznej - Komisji Edukacji Narodowej. Tego dnia na terenie szkoły organizowano różne przedstawienia, w celu upamiętnienia i podkreślenia znaczenia tej instytucji w dziejach polskiej nauki i kultury ${ }^{40}$.

Jak słusznie zauważył jeden z wychowanków lwowskiego gimnazjum: wszystkie te zabiegi wychowawcze koncentruja się $w$ szkole podczas obchodów szkolnych, które sta-

${ }_{35}$ M. Panek, op. cit., s. 42. We Lwowie powstała uczniowska orkiestra dęta, która została założona przez nauczyciela Emila Lewickiego, miłośnika śpiewu i muzyki. Orkiestra ta występowała podczas różnych uroczystości nie tylko we Lwowie, ale także koncertowała w Tarnowie, Wadowicach, Nowym Targu, Zakopanem, Krynicy i Nowym Sączu. W ten sposób kształtowała się kultura muzyczna wśród młodzieży, a przede wszystkim kształtował się nowy obyczaj.

${ }^{36}$ M. Opałek, Gawędy o dawnej..., s. 105.

37 Ibidem.

${ }^{38}$ M. Panek, op. cit., s. 39.

39 Ibidem, s. 42.

${ }^{40}$ K. Machalski, op. cit., s. 115. 
rannie przygotowane odbywaja się często $w$ auli zakładu, wiążac przeszłość z teraźniejszościa w celu spotęgowania uczuć patriotycznych i obywatelskich młodzieży ${ }^{41}$.

Literatura pamiętnikarska wskazuje, że do obyczajów szkolnych trzeba zaliczyć również wycieczki, organizowane przez nauczycieli. Przykładowo w gimnazjum w Rzeszowie kultywowano „wycieczki majówkowe”. Podczas tych imprez uczniowie wszystkich klas razem z nauczycielami przy dźwiękach muzyki wojskowej wędrowali do lasów głogowskich, a następnie każda klasa oddzielnie organizowała wyprawę w okoliczne lasy ${ }^{42}$. Z kolei nauczyciel Stanisław Rzepiński co tydzień w sobotę urządzał obowiązkowe wycieczki rekreacyjno-zdrowotne do pobliskich miejscowości dla uczniów IV Gimnazjum we Lwowie. Podczas tych wypraw młodzież śpiewała pieśni i hymny narodowe, w celu podniecania uczuć patriotycznych. Dodatkowo dzięki takim wycieczkom nauczyciele mieli sposobność lepszego poznania swoich wychowanków. Jak wspomniał S. Rzepiński przy zabawach na miejscu (biegi do mety, gra w piłkę, jazda konna i inne) było nie mało sposobności do poznania usposobień, temperamentu i zawiąku charakterów u uczniów ${ }^{43}$.

Na terenie zaboru austriackiego popularna również była działalność korpusów wakacyjnych, które przeznaczone były wyłącznie dla młodzieży szkolnej. Ich zadaniem było uczynić młodzież $w$ miastach uczestnikami choć $w$ części tych korzyści pedagogicznych $i$ higienicznych, jakie przedstawiaja kolonie ${ }^{44}$. Młodzież pod kierunkiem wykwalifikowanych nauczycieli wędrowała poza miasto. Jeden z uczestników tych korpusów wspominał wędrowaliśmy tak codziennie po radość $i$ zachwyty, wędrowaliśmy w różne strony, bo madrze obmyślano dla nas musztry $i$ na każdy dzień tygodnia wyznaczona była inna okolica ${ }^{45}$. Według przygotowanego programu młodzież także na świeżym powietrzu brała udział w ćwiczeniach gimnastycznych, musztrach, zabawach towarzyskich. Podczas tych wycieczek majówkowych społeczność szkolna śpiewała pieśni patriotyczne, m.in. Precz, precz smutek z czoła, a najchętniej śpiewano Marsyliankę $e^{46}$. Zgodnie z założeniami pomysłodawców wszelkie czynności podejmowane podczas korpusów wakacyjnych miały orzeźwiać ciało $i$ ducha młodzieży i nie dopuszczać do rozprzężenia, do jakiego młodzież pozostawiona sobie samej podczas wakacji dochodzić zwykła ${ }^{47}$. Idea korpusów

${ }^{41}$ Księga pamiątkowa 50-lecia Gimnazjum im. Jana Dlugosza we Lwowie, red. W. Kucharski, Lwów 1928, s. 44.

42 M. Panek, op. cit., s. 39.

43 S. Rzepiński, Pamiętnik pięćdziesięcioletniej polskiej pracy pedagogicznej 1885-1935, Kraków 1937, s. 15. Nauczyciel Stanisław Rzepiński pomysł organizowania takich wycieczek zaczerpnął od swego wychowawcy Józefa Czerneckiego, który w lecie w każdą sobotę organizował dla uczniów wycieczki we wschodnie okolice Lwowa. Podczas takich wypraw oprócz zabaw ruchowych młodzież zobowiązana była głosić deklamacje patriotyczne. Nauczyciel Czarnecki niektóre deklamacje nagradzał książkami. W Pamiętniku S. Rzepiński wspomniał, że otrzymał J. Chodziszewskiego Historię Polski, Piśmiennictwo Polskie oraz Lutnię - Piosennik Polski.

${ }^{44}$ M. Opałek, O Lwowie i mojej młodości ..., s. 91.

${ }^{45}$ Ibidem, s. 88.

${ }^{46}$ Ibidem.

47 Ibidem, s. 91. 
wakacyjnych spotkała się z wielką przychylnością ze strony uczniów galicyjskich. Jeden z jej uczestników wspominał: wspólne przeżycia na łonie natury zacieśniały mocniej węzty koleżeństwa. Miłość przyrody bogaciła emocjonalne wartości życia, trud pieszej wędrówki hartowat i prężyt mięśnie nóg, głębokie oddechy poszerzały klatkę piersio$w a^{48}$.

Z przeglądu źródeł pamiętnikarskich wynika, że w szkole, jak i poza jej murami pielęgnowano różne tradycje i obyczaje. Posiadały one podobną obrzędowość i odwoływały się do wartości patriotycznych i religijnych.

\section{Stosunek nauczycieli wobec tradycji i obyczajów}

Od momentu upadku państwa polskiego, niezwykle ważna w procesie kultywowania tradycji i obyczajów była edukacja szkolna. Wspomnienia dokumentują, że nauczyciele szkół galicyjskich podczas lekcji przekazywali wartości związane z polską tradycją i kulturą narodową. Odwoływali się zarówno do własnych doświadczeń, jak i wiedzy, którą zdobyli podczas przygotowania zawodowego. Jako przykład można przywołać nauczyciela lwowskiego Stefana Frycza, który opowiadał uczniom o Krakowie, o literatach tamtejszych, znat dużo ludzi z Młodej Polskit ${ }^{49}$, zaś nauczyciel krakowskiego gimnazjum Komorowski uczył historii przez zwiedzanie ważnych miejsc w mieście. Jeden z jego uczniów Bolesław Drobner ${ }^{50}$ tak wspominał te zajęcia: wodzil nas po ogrodzie za Brama Kościuszki po ścieżkach, którymi szedt Kościuszko od kościoła Kapucynów do Rynku Głównego w dniu 24 marca 1794 roku ${ }^{51}$. Historyk oświaty Stanisław Łempicki, odwołując się do wspomnień szkolnych, zaznaczył, że ksiądz Ciemniewski opowiadał swoim wychowankom o Adamie Mickiewiczu, jego działalności i innych ważnych romantykach, a także ludziach będących na emigracji i w kraju, którzy wpływali na odrodzenie narodowo-religijne Polaków. Nauczyciel Stanisław Rzepiński na kartach pamiętnika wspominał jednego ze swoich kolegów dra Alberta Zippera, wychowywanego w szkołach niemieckich, który jego zdaniem byt czujnym i pilnym rzecznikiem polskiej twórczości literackiej $i$ w ogóle polskiej kultury wobec Niemców, autor świetnych przekładów na język niemiecki: »Marii«, »Przenajświętszej Rodziny«, »Wiestawa«, »Ody do młodości«,

\footnotetext{
48 Ibidem, s. 88.

49 S. Łempicki, Ztote paski..., s. 82.

50 Stownik biograficzny działaczy polskiego ruchu robotniczego, red. F. Tych, Warszawa 1970, t. 1, s. 478-480. Bolesław Drobner - (ur. 28 czerwca 1883 w Krakowie, zm. 31 marca 1968 w Krakowie). Ukończył chemię na Uniwersytecie Jagiellońskim, z której otrzymał doktorat. Od 1898 działał w Polskiej Partii Socjalno-Demokratycznej Galicji i Śląska Cieszyńskiego, a następnie w Polskiej Partii Socjalistycznej. Po najeździe sowieckim na Polskę w dniu 17 września 1939 r. aresztowany przez NKWD i więziony. W 1943 został uwolniony i wszedł do władz Związku Patriotów Polskich. W 1945 r. został wybrany pierwszym polskim prezydentem Wrocławia. Zaprzyjaźniony z Piwnicą pod Baranami, pomógł w jej otwarciu i pierwszych latach działania.

51 B. Drobner, To już tak dawno, w: Kopiec wspomnień, red. S. Broniewski, Kraków 1959, s. 11.
} 
»Chorału« $i$ innych ${ }^{52}$. Warto także zaznaczyć, że nauczyciel języka niemieckiego Zygmunt Kunstmann apelował do młodzieży przede wszystkim do tradycyjnych cnót polskich, do naszego charakteru narodowego i honoru. Wtedy też przemawiat zawsze po polsk $u^{53}$. Trzeba podkreślić, że w proces przekazywania polskich tradycji i obyczajów włączali się nie tylko nauczyciele historii, ale i Ci uczący innych przedmiotów, m.in. geografii, matematyki, języka polskiego oraz języka niemieckiego.

Jednak nie wszyscy nauczyciele przekazywali dorobek polskiej nauki i kultury. Byli i tacy, którzy lekceważyli wartość tradycji i obyczajów, a nawet fałszowali informacje. Jako przykład warto podać nauczyciela, który zdaniem Kazimierza Chłędowskiego podczas zajęć szkolnych uczył „,bredni” zarówno w nauce historii powszechnej, jak i historii ojczystej, a nawet geografii ${ }^{54}$. W podobny sposób zachowywał się nauczyciel historii $\mathrm{w}$ gimnazjum we Lwowie. Jeden z uczniów tak wspominał te zajęcia: widzac jak nas profesor [Kraiński] okłamuje, przestaliśmy wierzyć wszystkim. W każdym profesorze widzieliśmy najętego od rządu niemieckiego kłamcę. Uczyliśmy się więc wszystkiego ze wstrętem, z obrzydzeniem, nie dlatego, żeby nabyć wiadomości pożytecznych, ale tylko dla otrzymania promocji z klasy do klasy ${ }^{55}$.

\section{Podsumowanie}

Podsumowując powyższe rozważania, trzeba zaznaczyć, że szkoły galicyjskie posiadały wiele tradycji i obyczajów, które w różny sposób kultywowały. Organizowane obchody charakteryzowały się podobnym obrządkiem, w celu upamiętniania polskiego dorobku kulturowego. Podczas uroczystości społeczność szkolna wsłuchiwała się w słowo mówione, głoszone z ambon kościelnych oraz okazjonalne przemówienia, odczyty, wykłady, a także brała udział w organizowanych marszach.

Odwołując się do tradycji i obyczajów szkolnych na terenie zaboru austriackiego, należy zaznaczyć, że kultywowano z jednej strony rocznice i święta narodowo-religijne, a z drugiej te charakterystyczne dla oświaty czy danej szkoły. Literatura pamiętnikarska potwierdza, że społeczność szkolna, czyli nauczyciele i uczniowie aktywnie włączali się $\mathrm{w}$ proces podtrzymania polskiej tradycji i obyczajów, mimo trudnego czasu, jakim był okres zaborów. Niewątpliwie z dotychczasowego przeglądu źródeł pamiętnikarskich wynika, że w tradycje i obyczaje szkolne wpisane były uroczystości poświęcone ważnym wydarzeniom w życiu narodu polskiego, czyli obchody Konstytucji 3 maja czy rocznic powstań narodowych. Mimo pojawiających się różnych represji ze strony zaborcy nauczyciele i uczniowie angażowali się w wydarzenia o charakterze religijnym. Równie wartościowe były tradycje, które upamiętniały dorobek zasłużonych osób w dziejach na-

\footnotetext{
52 S. Rzepiński, op. cit., s. 16.

53 S. Łempicki, Ztote paski..., s. 68-69.

${ }^{54}$ K. Chłędowski, Pamiętnik. Galicja (1843-1880), Kraków 1957, t. I, s. 92.

55 F. Skobel, Ofiara pedagogii austriackiej 1811-1822, w: Galicyjskie wspomnienia szkolne..., s. 22. Kraiński - nauczyciel historii w gimnazjum we Lwowie.
} 
uki i kultury. Jako przykład można wymienić te poświęcone bohaterom narodowym, walczącym na rzecz swojej Ojczyzny - Tadeuszowi Kościuszce czy bohaterom literackim - Adamowi Mickiewiczowi.

Ważne miejsce w tradycji i obyczajach szkolnych zajmowały uroczystości związane z funkcjonowaniem instytucji oświatowych, m.in. rozpoczęcie i zakończenie roku szkolnego czy jubileusze szkolne. Na podstawie wspomnień należy zaznaczyć, że w procesie kultywowania tych tradycji szczególnie znacząca była postawa nauczycieli. Dzięki ich zaangażowaniu w uroczystości szkolne i pozaszkolne, uczniowie szkół galicyjskich poznali tradycje i obyczaje, a także włączali się w proces ich przekazu kolejnym pokoleniom Polaków.

Warto także podkreślić, że organizowane obchody miały zazwyczaj podwójny wymiar. Oprócz przypomnienia wydarzeń związanych z dziejami polskiego narodu, stanowiły istotny element $\mathrm{w}$ procesie podtrzymania świadomości narodowej, zwłaszcza wśród młodego pokolenia Polaków. Szczególnie w okresie zaborów nie sposób pominąć istotnego znaczenia, jakie nadawano uroczystościom i manifestacjom, przypominającym ważne chwile z dziejów ojczystych i osoby zasłużone dla Polski, które w zasadniczy sposób kształtowały postawy patriotyczne społeczności szkolnej. Literatura pamiętnikarska potwierdza, że pielęgnowane przez szkołę tradycje i obyczaje stanowily również szczególny rodzaj „edukacji” historycznej, a zarazem integrowały społeczność szkolną oraz nadawały jej niepowtarzalny charakter. 